\title{
ANALISIS KEGIATAN EKSTRAKURIKULER MEMBATIK TERHADAP KEMAMPUAN MEMBATIK SENI RUPA SISWA SEKOLAH DASAR DI DESA MANTINGAN, KECAMATAN JAKEN, KABUPATEN PATI
}

\section{Rizky Alfiana ${ }^{\bowtie}$, Djariyo, dan Filia Prima Artharina}

Prodi Pendidikan Guru Sekolah Dasar, FIP, Universitas PGRI Semarang

\section{Info Artikel \\ Abstract \\ Sejarah Artikel: \\ Diterima 24 Agt 2017 \\ Disetujui 30 Okt 2017 \\ Dipublikasikan Des 2017

Keywords:
Extracurricular, Batik,
Ability to make art \\ This research is describe the analysis of batik extracurricular activities to the ability of batik painting of elementary school students in Mantingan Village, Jaken Sub-district, Pati Regency. This research uses qualitative descriptive approach with principal subject, extracurricular batik trainer, and students of SD N Mantingan. The object of this study is the analysis of batik extracurricular activities on the ability of art batik. Data collection is done by observation, interview. The data analysis techniques include data collection, data reduction, data presentation, and conclusion. To test the validity of the data used persistence. Batik extracurricular activities that have been implemented in SD N Mantingan have a role on the ability of batik art to produce various works of batik art. The ability of batik art, among others, elements and principles of art are taught by trainers or teachers able to make students can be creative, work, develop creativity, express feelings, talents, motivation and independence.}

\begin{abstract}
Abstrak
Penelitian ini adalah mendeskripsikan analisis kegiatan ekstrakurikuler membatik terhadap kemampuan membatik seni rupa siswa sekolah dasar di Desa Mantingan, Kecamatan Jaken, Kabupaten Pati. Penelitian ini menggunakan pendekatan deskriptif kualitatif dengan subjek kepala sekolah, pelatih ekstrakurikuler membatik, dan siswa SD N Mantingan. Objek penelitian ini adalah analisis kegiatan ekstrakurikuler membatik terhadap kemampuan membatik seni rupa. Pengumpulan data dilakukan dengan cara observasi, wawancara. Adapun teknik analisis data meliputi pengumpulan data, reduksi data, penyajian data, serta penarikan kesimpulan. Untuk uji keabsahan data digunakan ketekunan/keajegan pengamatan dan trianggulasi. Kegiatan ekstrakurikuler membatik yang telah dilaksanakan di SD N Mantingan memiliki peran terhadap kemampuan membatik seni rupa sehingga menghasilkan berbagai karya seni batik. Kemampuan membatik seni rupa antara lain unsur dan prinsip seni yang diajarkan oleh pelatih atau guru mampu membuat siwa dapat berkreasi, berkarya, mengembangkan kreativitas, mengungkapkan perasaan, bakat, motivasi dan mandiri.
\end{abstract}

(C) 2017 Universitas Muria Kudus

Alamat korespondensi:

Program Studi Pendidikan Guru Sekolah Dasar

Fakultas Keguruan dan Ilmu Pendidikan Universitas Muria Kudus

Kampus UMK Gondangmanis, Bae Kudus Gd. L. 1t I PO. BOX 53

Kudus

Tlp (0291) 438229 ex.147 Fax. (0291) 437198

E-mail: rizkyalfiana27@gmail.com 


\section{PENDAHULUAN}

Permendikbud No 62 Tahun 2014 pada Pasal 1 dan 2 menegaskan bahwa kegiatan esktrakulikuler adalah kegiatan kurikuler yang dilakukan oleh peserta didik diluar jam belajar kegiatan intrakurikuler dan kegiatan kokulikuler, di bawah bimbingan dan pengawasan satuan pendidikan. Kegiatan esktrakurikuler diselenggarakan dengan tujuan untuk mengembangkan potensi, bakat, minat, kemampuan, kepribadian, kerjasama, dan kemandirian peserta didik secara optimal dalam rangka mendukung pencapaian tujuan pendidikan nasional. Adapun kegiatan intrakurikuler diselenggarakan melalui kegiatan terstruktur dan terjadwal, sesuai dengan tingkat kompetensi muatan serta mata pelajaran, sedangkan kegiatan kokurikuler dilaksanakan melalui penugasan terstruktur terkait satu atau lebih dari muatan atau mata pelajaran.

Kurikulum yang dipakai di SD N Mantingan Kecamatan Jaken Kabupaten Pati saat ini memakai Kurikulum Tingkat Satuan Pendidikan (KTSP), pada mata pelajaran Seni Budaya dan Keterampilan dibagi menjadi seni musik, seni rupa dan seni tari, setiap siswa berhak memilih salah satu bidang yang sesuai dengan minat dan bakat yang dimiliki. Mengingat potensi lokal di daerah pati salah satunya adalah membatik, yang terkenal dengan batik bakaran, maka untuk membekali keterampilan siswa di SD N Mantingan Kecamatan Jaken Kabupaten Pati diselenggarakan kegiatan ekstrakurikuler membatik. Berdasarkan hasil observasi dan wawancara pada tanggal 24 Maret 2017 dengan Bapak Srihadi selaku kepala sekolah di SD N Mantingan menyatakan bahwa pelaksanakaan kegiatan esktrakurikuler yang ada di SD N Mantingan meliputi praktek membatik, yang dilaksanakan setiap hari sabtu, kegiatan ekstrakurikuler ini diikuti mulai dari siswa kelas $3-5$.

Observasi awal menjelaskan bahwa mayoritas masyarakat Mantingan adalah masyarakat seni, akan tetapi tidak sebanding dengan mata pencaharian masyarakat yang mayoritasnya sebagai petani. Masyarakat Mantingan memiliki bakat terpendam dalam diri mereka yakni bakat kesenian, akan tetapi bakat yang dimiliki masyarakat Mantingan tidak tersalurkan, dikarenakan kurangnya pengetahuan, kurangnya pemahaman akan peningkatan perekonomian dalam kehidupan masyarakat mantingan dan mengembangkan desanya agar dikenal masyarakat luas.

Berdasarkan permasalahan yang ada di Desa Mantingan diharapkan mampu melestarikan dan mengembangkan bakat yang dimiliki masyarakat mantingan tersebut agar bakat yang ada dapat lebih dikembangkan. Adanya bakat tersebut siswa mampu melestarikan potensi lokal yang ada di desa mantingan.

Hasil observasi yang sama juga diperoleh bahwa kegiatan ekstrakurikuler membatik yang ada di SD N Mantingan sudah sesuai dengan prosesnya yaitu dari proses pembuatan pola dikain, menjiplak pola kekain, proses penglowongan sampai proses pewarnaan, pada dasarnya sama, hal ini diharapkan bahwa seni sebelumnya sudah ada dikegiatan ekstrakurikuler tersebut, namun di SD N Mantingan umumnya tidak memperhatikan unsur dan prinsip dari seni rupa yang seharusnya diperhatikan dalam prakteknya dikarenakan unsur subyektivitas yang tinggi pada penilaian seni rupa dalam kegiatan ekstrakurikuler membatik. Selain itu seni rupa dalam membatik merupakan bentuk ekspresi manusia yang juga tercipta turun temurun dari masa lalu. Karya seni tersebut merupakan kebudayaan.

Kegiatan esktrakulikuler yang melibatkan siswa dan pihak sekolah dalam rangka meningkatkan bakat dan minat siswa dalam kegiatan membatik dengan mengajarkan cara membatik sebagai wujud penerus bangsa yang diharapkan nantinya dapat melestarikan batik yang ada di Kabupaten Pati. Oleh karena itu penulis tertarik untuk meneliti tentang "Analisis Kegiatan Ekstrakurikuler Membatik Terhadap Kemampuan Membatik Seni Rupa Siswa SD di Desa Mantingan Kecamatan Jaken Kabupaten Pati”.

\section{METODE PENELITIAN}

Penelitian ini menggunakan pendekatan kualitatif dengan jenis deskriptif. Penelitian dilaksanakan pada tanggal 8, 15, 22, 29 Januari 2017 dan dilanjutkan pada tanggal 24 Maret dan 9 April 2017.

Penelitian bertempat di SD N Mantingan, Kecamatan Jaken, Kabupaten Pati. Subjek dalam penelitian ini adalah Kepala Sekolah, Pelatih ekstrakurikuler membatik dan siswa peserta kegiatan ekstrakurikuler membatik.

Pada penelitian ini pengumpulan data dilakukan menggunakan teknik observasi, wawancara, dan dokumentasi. Instrumen yang digunakan yaitu panduan observasi dan panduan wawancara.

Observasi dilakukan untuk mengamati kegiatan ekstrakurikuler membatik yang ada di SD N Mantingan. Wawancara yang diperoleh dalam penelitian ini berupa rekaman suara yang 
dilakukan kepala sekolah SD N Mantingan dan guru/pelatih batik SD N Mantingan.

Analisis data yang digunakan dalam penelitian ini adalah teknik analisis data kualitatif.

\section{HASIL PENELITIAN DAN PEMBAHASAN} Hasil penelitian

\section{Kegiatan Ekstrakurikuler SD N Mantingan, Kecamatan Jaken, Kabupaten Pati}

Kegiatan ekstrakurikuler membatik yang ada di SD N Mantingan dapat menumbuhkan bakat dan minat yang terpendam dalam diri siswa, meskipun kegiatan ekstrakurikuler yang ada di SD N Mantingan ini sangat banyak, tetapi siswa tidak diwajibkan untuk mengikuti semua kegiatan esktrakurikuler tersebut, hanya siswa yang memiliki bakat dan minat yang sesuai dalam masing-masing keahliannya. Hal ini diperkuat dalam wawancara dengan kepala sekolah Bapak Srihadi mengatakan bahwa minat siswa yang ada di SD N Mantingan dalam kegiatan ekstrakurikuler sangat luar biasa, semuanya senang, tetapi kita juga bisa melihat anak mana yang sesuai dengan bakatnya, anak yang bisa membatik diarahkan mengikuti ekstrakurikuler membatik, yang suka gamelan diarahkan ke ekstrakurikuler karawitan, dan yang sesuai dengan kahliaan anak di bidang masingmasing kegiatan ekstrakurikuler lainnya.

Hal ini sesuai dengan pendapat Slameto dalam Fadillah (2016: 116) yang mengatakan bahwa minat dapat menjadi motivasi yang mendorong seseorang untuk melakukan apa yang diinginkan. Minat mempunyai peranan sangat penting dalam perkembangan belajar siswa. Siswa yang menaruh minat pada suatu bidang tertentu, maka akan berusaha lebih keras dalam menekuni bidang tersebut dibanding siswa yang tidak menaruh minat.

Berdasarkan pembahasan diatas, minat yang ada pada diri siswa harus selalu dikembangkan terus menerus karena mempunyai peranan penting bagi perkembangan IQ dan EQ pada siswa.

\section{Kemampuan Membatik Seni Rupa Di SD N Mantingan, Kecamatan Jaken, Kabupaten Pati}

Kemampuan membatik seni rupa yang didadakan di SD N Mantingan ini memiliki ketegori yang baik. Hal ini sesuai dengan hasil penilaian karya siswa dalam kegiatan ekstrakurikuler membatik yang ada di SD N Mantingan, Kecamatan Jaken, Kabupaten Pati. Hasil penilaian tersebut dapat dilihat pada Gambar 1 berikut.

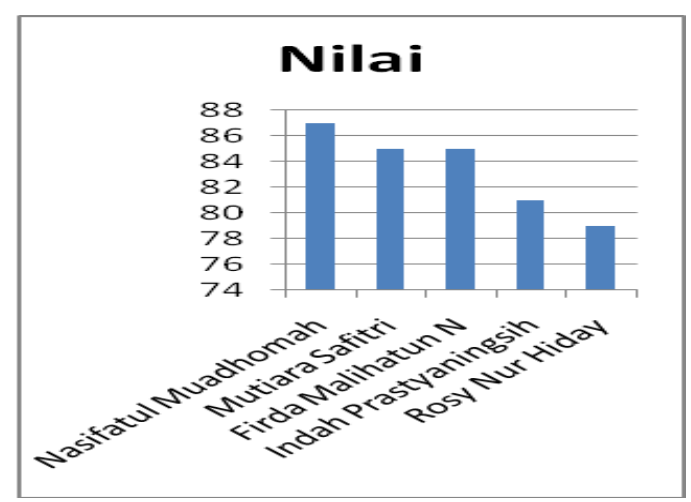

Gambar 1. Hasil penilaian karya siswa

Pada dasarnya kegiatan ekstrakurikuler membatik di SD N Mantingan Kecamatan Jaken Kabupaten Pati terlaksana cukup baik, tetapi di dalam kegiatan tersebut siswa hanya mengetahui proses pada umumnya, padahal dalam kemampuan membatik seni rupa terdapat unsur dan prinsip seni yang harus diketahui dan dipahami siswa. Hal ini disebabkan siswa kelas III - V masih dalam tahap latihan dan belajar, sehingga batikan siswa masih kurang maksimal dan harus ditingkatkan lagi. Pada pelaksanaan kegiatan, setelah siswa diajarkan adanya unsur dan prinsip dalam kemampuan membatik, ada 5 hasil karya siswa dapat dikategorikan sangat baik.

Hal ini sesuai dengan pendapat Susanto (2013: 268-269) yang mengatakan bahwa evaluasi pembelajaran SBK aspek lebih menekankan kepada kepada proses kreatif. Proses kreatif mengacu aktivitas siswa untuk berkreasi secara spontan berdasarkan imajinasinya. Menumbuhkan respon kreatif pada siswa sekolah dasar diperlukann stimulus (rangsangan). Rangsangan mampu membangkitkan motivasi, imajinasi dan inspirasinya. Berdasarkan pembahasan diatas dapat disimpulkan bahwa membatik mampu menumbuhkan imajinasi dan kreativitas siswa, sehingga siswa dapat menghasilkan karya seni siswa yang bernilai tinggi.

Berdasarkan penilaian bahwa hasil karya siswa dalam kegiatan ekstrakurikuler membatik yang ada di SD N Mantingan memiliki penilaian yang dapat dikategorikan baik, kelima hasil karya yang dihasilkan siswa selalu mendapatkan apresiasi yang baik dari pihak sekolah, maupun pihak dari luar sekolah. Karya yang dihasilkan selalu mendapat juara umum baik dari tingkat kecamatan maupun kabupaten.

Pada penilaian karya tersebut juga sudah sesuai dengan aspek yang dinilai oleh peneliti dan menghasilkan hasil yang cukup baik serta memuaskan. Kelima hasil karya siswa tersebut 3 dari 5 siswa mendapatkan nilai yang cukup 
tinggi dan 2 dari 5 siswa mendapatkan nilai sedang. Namun demikian secara keseluruhan karya yang dihasilkan dari siswa-siswi yang ada di SD N Mantingan sudah sangat baik dan dapat dikembangkan lagi menjadi hasil produksi yang lebih banyak dan lebih baik lagi untuk kedepannya.

Hal ini sesuai dengan pendapat Susanto (2013: 265) yang mengatakan bahwa tujuan pembelajaran SBK memiliki fungsi dan tujuan untuk mengembangkan sikap dan kemampuan siswa mampu berkreasi dan peka dalam kesenian, serta memberikan kemampuan dalam berkarya dan berapreasiasi.

Berdasarkan pembahasan diatas, bahwa hasil karya membatik yang ada di SD N Mantingan, dengan adanya membatik, siswa mampu berkreasi sesuai dengan imajinasi siswa, dari kreasi tersebut siswa mampu menghasilkan hasil karya seni, dan hasil karya tersebut dapat memberikan apresiasi positif untuk sekolah yang ada di SD N Mantingan.

\section{Pembahasan}

Kegiatan ekstrakurikuler membatik yang telah dilaksanakan di SD N Mantingan memiliki peran terhadap kemampuan membatik seni rupa sehingga menghasilkan berbagai karya seni batik. Kemampuan membatik seni rupa antara lain unsur dan prinsip seni yang diajarkan oleh pelatih atau guru mampu membuat siwa dapat berkreasi, berkarya, mengembangkan kreativitas, mengungkapkan perasaan, bakat, motivasi dan mandiri.

Hal ini sesuai dengan pendapat Sari (2013: 69) yang mengatakan bahwa manfaat belajar membatik salah satunya menyeimbangkan otak kanan dan otak kiri, otak kanan adalah tempat untuk perkembangaan halhal yang bersifat artistik, kreativitas, perasaan, emosi, kemampuan intuitif, musik, imajinasi, khayalan, warna, pengenalan diri dengan orang lain, sosialisasi, dan pengembangan kepribadian. Sementara itu, otak kiri berkaitan dengan fungsi akademik, berbicara, kemampuan tata bahasa, baca tulis, daya ingat, pusat matematika, analisis, dan lain-lain. Otak kiri lebih baik dari pada otak kanan atau sebaliknya bahwa aktivitas otak kanan dan otak kiri terutama pada anak-anak kadang menjadi tidak seimbang dari aktivitas sekolah dimana proses belajar mengajar lebih banyak mengasah kemampuan otak kiri dan sedikit sekali mengembangan otak kanan.

Berdasarkan pembahasan diatas, dengan adanya membatik otak kanan dan otak kiri menjadi terasah, sehingga adanya motivasi, kemampuan bereksplorasi, kreativitas, dan kemandirian mampu menjadi pembiasaan pada diri siswa. Melalui ekstrakurikuler membatik siswa dapat terampil dalam membatik yang sesuai dengan ketentuanya dan mampu mengembangkan bakatnya, membuat kreasi sesuai dengan imajinasi siswa, mengembangkan kreativitas, mampu membantu siswa mengungkapkan perasaan, menambah minat, membarikan bekal pada siswa, serta melatih kemandirian pada siswa.

Hal ini sesuai dengan pendapat Susanto (2013: 266-267) yang mengatakan bahwa memilih metode yang akan digunakan guru dalam program kegiatan pembelajaran, guru hendaknya kreatif dalam memilih metode yang dipakai. Sehingga dengan pemilihan metode yang tepat, mampu menumbuhkan dan mengembangkan seluruh potensi yang dimiliki siswa agar dapat menghasilkan sesuatu berdasarkan daya pikir atau kemampuannya. Pemilihan metode yang tepat dapat membantu pembentukan kepribadian anak. Selain itu dengan pemilihan metode yang tepat diharapkan anak dapat menyalurkan ekspreasi jiwanya, menumbuhkan keberanian berkreasi yaitu menyalurkan pikiran dan perasaan. Berdasarkan pembahasaan diatas, bahwa adanya metode dan materi yang dipilih guru dapat menghasilkan karya seni membatik siswwa dari awalnya kurang maksimal menjadi lebih baik dari sebelumnya.

\section{SIMPULAN}

Berdasarkan temuan hasil analisis penelitian dan pembahasan yang telah diuraikan dapat disimpulkan sebagai berikut.

1. Kegiatan ekstrakurikuler membatik sangatlah berpengaruh pada kemampuan membatik seni rupa bagi siswa di SD N Mantingan Kecamatan Jaken, Kabupaten Pati. Pada hasil penilaian yang sudah dilakukan bahwa hasil karya siswa yang ada di SD N Mantingan mendapatkan hasil yang memuaskan dan dapat nilai baik, 3 dari 5 siswa mendapatkan nilai yang cukup tinggi, sedangkan 2 dari 5 siswa mendapatkan hasil yang masih sedang, tetapi seluruh hasil karya siswa termasuk dalam kategori yang cukup baik. Hal ini terlihat adanya kegiatan ekstrakurikuler membatik terhadap kemampuan membatik seni rupa berpengaruh pada hasil karya seni siswa.

2. Kemampuan membatik seni rupa mampu membuat siwa dapat berkreasi, berkarya, mengembangkan kreativitas, mengungkapkan perasaan, bakat, motivasi dan mandiri. Dengan kegiatan membatik otak kanan dan otak kiri menjadi terasah, 
sehingga adanya motivasi, kemampuan bereksplorasi, kreatifitas, dan kemandirian mampu menjadi pembiasaan pada diri siswa.

Saran bagi pengembangan kegiatan ekstrakurikuler membatik yaitu:

1. Bagi Sekolah diharapkan bisa melengkapi fasilitas sekolah untuk penunjang dalam kegiatan ekstrakurikuler yang ada di SD N Mantingan, misalnya pihak sekolah menyediakan sarana berupa ruang khusus untuk ekstrakurikuler membatik untuk sebagai wadah apresiasi dan kreasi siswa dalam mendukung keberlangsungan pembelajaran ekstrakurikuler membatik agar lebih efektif.

2. Bagi siswa diharapkan dapat lebih mengenal budaya indonesia dan setelah melaksanakan proses kegiatan ekstrakurikuler membatik ini, siswa dapat membuat hasil karya sesuai dengan budaya bangsa dengan lebih baik

\section{DAFTAR PUSTAKA}

Arikunto, Suharsimi. 2008. Manajemen Pendidikan. Yogyakarta: Aditya Media bekerjasama dengan Fakultas Ilmu Pendidikan (FIP) Universitas Negeri Yogyakarta.
Kamaril, Cut. 2001. Pendidikan Seni Rupa /Kerajinan Tangan. Banten: Unversitas Terbuka.

Fadillah, Ahmad. 2016. Analisis Minat Belajar Dan Bakat Terhadap Hasil Belajar Matematika Siswa. Jurnal: Universitas Muhammadiyah Tangerang Moleong, Lexy.J. 2012. Metodologi Penelitian Kualitatif. Bandung: Rosda.

Peraturan Menteri Pendidikan dan Kebudayaan No 62 Tahun 2014 tentang Kegiatan Ekstakurikuler.

Sari, Rina Pandan. 2013. Ketrampilan Membatik Untuk Anak. Solo: Arcita.

Sugiyono. 2015. Metode Penelitian Pendidikan Pendekatan Kuantitatif, Kualitataif, dan $R \& D$. Bandung: Alfabeta.

Susanto, Ahmad. 2013. Teori Belajar dan Pembelajaran di Sekolah Dasar. Jakarta: Kencana. 